\title{
Inflation in the Kingdom of Saudi Arabia: The bound test analysis
}

\author{
Khalid Al Khathlan \\ Economics Department, King Saud University, P. O. Box 2459, Riyadh 11451, Kingdom of Saudi Arabia. \\ E-mail: kaa8161@hotmail.com.
}

Accepted 15 July, 2011

\begin{abstract}
The Kingdom of Saudi Arabia has been witnessing a rise in prices for the past few years. This paper intends to examine the determinants of inflation, both in the long run as well as in the short run, using cointegration method developed by Pesaran et al. (2001). The result shows that inflation in world economy, depreciation of domestic currency and supply bottlenecks are the major factors influencing inflation in the long run. In the short run, money supply and supply bottlenecks have been found to be the major factors influencing inflation in the country.
\end{abstract}

Key words: Inflation, exchange rate, foreign inflation, money supply, supply bottleneck, bound test.

\section{INTRODUCTION}

Since the 1980s, oil rich Gulf States have pegged their exchange rate with US dollar and benefitted on many ways. However, since 2006, the depreciation of dollar against Euro is creating problems for these countries in terms of inflation. Saudi Arabia also has benefitted from the relative stability of US monetary policy by pegging its currency with US dollar. The system has insulated the oil revenue in the budget from the exchange rate volatility, and stabilized the value of assets as large part of oil revenue which is invested in dollar denominated assets. However, with the depreciation of dollar vis a vis Euro and other currencies, the country is now facing challenges in terms of rising inflation. Price rose by about $6 \%$ in 2007, then reached double digit in 2008. In 2009, though inflation declined to about $5 \%$, it is still high in comparison to 1990s and early period of the current century.

One of the reasons for the rise in price level, as postulated by many, is Riyal's fixed exchange rate with the US dollar. The depreciation of dollar relative to Euro

Abbreviations: PPP, Purchasing power parity; WPI, wholesale price index; CPI, consumer price index; OLS, ordinary least squares; VAR, vector autoregressive; GCC, Gulf Cooperation Council; GDP, gross domestic product; UECM, unrestricted error correction model; ARDL, autoregressive distributed lag; $\mathbf{A R C H}$, autoregressive conditional heteroscedasticity. and other currencies mean depreciation of to these currencies. The direct effect of this is that it makes import costlier than before. Import from USA constitute less than $15 \%$ of Saudi's total imports, the depreciation of Riyal make import from other countries more expensive. As Saudi, to a large extent depends upon import in the absence of sufficient domestic production, the rise in import price causes rise in price level in the country. This is further reinforced by the rising prices of essential commodities all over the world.

Further, this system of pegged exchange rate sometimes adversely affects the economy by reducing the autonomy of country's monetary policy. For example, reduction in interest rate by US Federal Reserves from 5.25 to $2 \%$ in 2007 , forced Saudi to cut their interest rate in order to match interest rate parity. This was necessary because investor around the world would have flooded the country with funds seeking higher return on investment. This was terrible for Saudi Arabia as it was already experiencing a rising inflation (Feldstein, 2008).

Another factor which is considered as contributing to inflation is increase in oil revenue. The increase in oil revenue due to increase in oil price has not only boosted the rate of economic growth, it also caused the country flooded by cash. The increase in government revenue increased the government expenditure, generating demand in the economy. This along with some bottlenecks on the supply side, particularly in real estate, created a 
gap between demand and supply, causing inflation. The paper examines the determinants of inflation in Saudi Arabia, including both, domestic as well as external factors. The paper is structured as follows. Subsequently, the literature review is presented briefly. This is followed by a description of the model specification and methodology. The empirical result and its analysis is given and finally the conclusion.

\section{LITERATURE REVIEW}

\section{Theoretical foundation of inflation}

The inflationary process has been a controversial topic in the literature, both theoretically as well as empirically. The precise nature of the relationship of price level with other macroeconomic variables has (despite years of research) remained an area of concern. Number of factors act on each other and in turn affect the price level in an economy. It is not easy to decompose the observed inflation into various factors contributing it. Accordingly, different theories are evolved to explain the determinants of inflation.

Purchasing power parity (PPP) theory suggests that the price in the trading country should be same when expressed in common currency with the differential being accounted for by tariffs and transport costs. Rate of inflation of dominant countries influence the rate of inflation in smaller countries. The relationship of inflation of the two countries can be expressed as:

$\mathrm{P}_{d}=\mathrm{e}+\mathrm{P}_{f}$

Where $\mathrm{P}_{d}$ is domestic price level, $\mathrm{e}=$ nominal exchange rate and $\mathrm{P}_{f}=$ foreign price level.

In a country which is highly dependent on import from other country, change in either exchange rate or foreign price would also cause change in price level in the domestic country. In the case of Saudi Arabia, the depreciation of Riyal on account of depreciation of dollar may cause increase in price level. Similarly, the increase in price of some commodities in world market would also have its spillover effect on Saudi price. Proponents of quantity theory of money are of the view that inflation is a monetary phenomenon and is result of increase of money supply at a greater rate than that of output. Increase in cost of production is transferred into general price rise when money supply is increased. Under cost push theory, prices rise due to increase in cost of production. Prices rise either because of increase in wages or interest rate in the country, or due to increase in price of inputs imported from other countries as a result of inflation in foreign countries or depreciation of the domestic currency. Demand pull theory says that the inflationary process arises because of increase in demand of goods and services, either due to some unforeseen circumstances or due to expansionary fiscal and monetary policies. Increase in demand leads to increase in profit that generates additional excess demand for goods and services. This in turn increases the demand for factors of production leading to increase in their prices. This generates wage price spiral and inflation continues. In order to control this, a tight monetary and is required. Another development in the theory of inflation is rational expectation theory. According to this theory, expectation also plays an important role in influencing price level in an economy. It is viewed that economic agents, on the basis of past and current relevant information, form their macroeconomic expectations rationally. Thus simply announcing a policy to contain inflation will not check inflation. People on the basis of past and present information forecast about the expected price. Policy credibility and reputation thus forms an integrated part of any disinflationary policy. Recently, political instability and policy incredibility is also regarded a factor that affects the inflation in a country.

\section{Empirical studies}

lyoha (1973) used a sample of 33 less developed countries and analysed the relationship for both yearly and 5year averaged data from 1960/1 through 1964/5. The Ordinary Least Squares (OLS) was used in this study. The paper related inflation [proxied by rate of growth of wholesale price index (WPI) or consumer price index $(\mathrm{CPI})]$ and openness in simple bivariate framework. It was found that openness is negatively related to inflation. However, the results in the multivariate exercise were not unambiguous although openness variable always had negative sign, but it was found to be significant only occasionally. Changes in income and money growth were the other explanatory variables found to be significant when used separately. Otherwise, change in income variable tended to dominate the money growth variable. Keran (1979) concludes that there is marginal difference in inflation determinants in Saudi Arabia and the world, that too of degree and not of kind. He found that domestic inflation is influenced by world price measured in terms of export price of major industrialized countries and monetary growth. Onis and Ozmucur (1990) applied vector autoregressive models (VAR) and simultaneous equation model on monthly data, and found that, devaluation and supply side factors were the main factors affecting the inflation in Turkey. Juselius (1992) investigated the price behavior in Denmark using three kinds of macroeconomic explanations of inflation and found that deviation from steady state is the main cause of inflation in Denmark. Further, foreign factors like exchange rate and interest rate are found to be more important factor of price rise.

Darrat (1993) found that in Saudi Arabia, during the period 1962 - 1981, monetary growth, foreign interest rate and inflationary expectation are important determinants of inflation. Metin (1995) in his study on Turkey found that fiscal expansion is the main factor responsible for inflation during 1950 - 1988. Excess money demand 
also has positive relation with price rise in the short run. Besides, devaluation also has some affect on inflation.

Lim and Papi (1997) in the case of Turkey found that monetary variables like money and exchange rate depreciation are more important determinant of inflation during the period 1970 - 1995. The number of empirical studies has also been done to examine the issue of inflation. De Brower and Erricson (1998), have developed used mark up model to examine the inflation in Australia and found that the consumer price is a mark up over domestic and import cost with adjustment for dynamic and relative aggregate demand.

Using vector autoregressive method, Jin (2000) in his analysis of East Asian economies found that fiscal policy and foreign price shocks are important determinants of inflation. Besides, openness is also found to be influencing inflation of a country. Sekine (2001) found that in the case of Japan, mark up relationship, excess money and output gap are important determinants of inflation. Khan and Schimmelpfening (2006) in the case of Pakistan found that broad money growth and private sector credit growth are the key variables determining inflation. Wheat support price affects the price only in the short run and not in the long run.

Bonato (2007) finds strong relation between money growth and inflation in the long run as well as in the short run in Iran. He found long run relationship between price level, money, output, rate of return on money and exchange rate. This relation is also found valid in the short run. Cheung (2009) has found that in seven of the Industrialized countries, commodity price is important signal for inflation in these countries. Further, Cheung (2009) found that commodity price movement can provide larger signals for inflation in the commodity exporting countries than the commodity importing countries.

Kandil and Morsy (2009) while studying Gulf Cooperation Council (GCC) countries found that inflation in foreign countries have positively affected the prices in four of GCC countries, including Saudi Arabia, in the long run. Depreciation of domestic currency has also been found to be contributing to inflation in the long run in four of the countries including Saudi Arabia. The effect of government expenditure has been mixed one, but not significant in the case of Saudi Arabia. Similarly, effect of money supply has not been significant in the case of Saudi Arabia. In the short run, food prices and inflation in foreign countries have been found to be significant in the case of Saudi Arabia.

\section{MODEL SPECIFICATION, DATA AND METHODOLOGY}

Saudi Arabia is following a policy of pegged exchange rate with US dollar. The recent depreciation of dollar is causing depreciation of Saudi Riyal also against non dollar currencies. This makes the import costlier even though there is no increase in price in trading partner countries. Since the country to a large extent depends upon import, and import from USA constitutes only about $15 \%$ of total Saudi's import, the country has to pay higher price for the same commodities imported from other countries in terms of riyal. The rise in price of imports is reflected in rise in domestic price level. This way the country is exposed to external inflation. The rise in international prices since 2007 particularly of food products, have further compounded the problem.

According to the quantity theory, inflation is monetary phenomenon in the long run. That is sustained inflation is function of monetary growth. Because of pegged exchange rate, the monetary authority does not have much flexibility in her monetary policy. Increase in foreign reserves owing to higher oil revenue also led to increase in money supply. Further, increase in oil revenue has increased the purchasing power of the people. This along with high living standard has increased the aggregate demand in the country. In order to achieve high rate of growth and become self dependent, there is high rate of growth in government expenditure over the past years. Government expenditure has two prone effects. On the one hand, it generates demand in the market thus increase the overall demand in the economy and fuel the inflation in the economy. On the other hand, it also increases the productive capacity of the economy and hence the supply capacity of the economy. This way it has an adverse effect on inflation by meeting a part of increased demand. Net effect on inflation depends upon the difference between the increased demand and increase in productive capacity of the economy during the period concerned. Supply bottleneck is also one of the factors that influence the price level in the country. To estimate the effect of supply bottleneck, gross domestic product (GDP) gap has been taken in the model which is the difference between actual GDP and potential GDP.

$P=f(M S, N E E R, P w$, GDP gap)

Thus:

$P=\alpha+\beta_{1} M S+\beta_{2} N E E R+\beta_{3} P w+\beta_{4} G D P g a p+u_{i}$

Where $P$ is inflation in Saudi Arabia measured in terms of consumer price index, MS is money supply in the country, NEER is nominal effective exchange rate, $\mathrm{Pw}$ is world price level measured in terms of price index of the world, and GDP gap are supply bottleneck which is the difference between actual GDP and potential GDP. The direction of relationship among these variables may be stated as follows. Increase in money supply increases the liquidity in the economy and increase the demand in the economy. Increase in demand puts an upward pressure on the price level. Depreciation of currency makes the import costlier and would lead to rise in the price even if there is no increase in world price level. Increase in world price would further put additional pressure on the price. Higher the GDP gap or supply bottleneck, lower would be the pressure on the price level. All the variables are in natural log form. The data on these variables are taken from World Development Indicator (2009) published by World Bank, and Annual Report of Saudi Arabian Monetary Agency (2010).

The empirical analysis in this paper is based on annual time series data for the period 1980 to 2009 . But the problem with the time series data is that the data may not be stationary at level. Regressing the non-stationary variable on other non-stationary variables may sometimes give spurious results. In order to avoid that, first of all, stationary test of these variables have been conducted. For the purpose, Augmented Dicky- Fuller (ADF) test and Philips-perron (PP) test will be applied. The ADF is based on the assumption that the error term is statistically independent and have a constant variance. Philips and Perron (1988) developed a generalization of the ADF test procedure that allows for fairly mild assumptions concerning the distribution of errors. While the ADF test corrects for higher order serial correlation by adding the lagged difference term on the right hand side, the PP test makes a correction to the t-statistics of the coefficient from the AR (1) regression to account for the serial correlation in residual term. So 
Table 1. Result of stationary test.

\begin{tabular}{lcccc}
\hline \multirow{2}{*}{ Variable } & \multicolumn{2}{c}{ ADF Test } & \multicolumn{2}{c}{ PP Test } \\
\cline { 2 - 5 } & Level & First difference & Level & First difference \\
\hline IP & -1.137324 & $-4.704936^{*}$ & -1.428760 & $-4.698041^{*}$ \\
INEER & -0.125371 & $-2.944489^{\star * *}$ & 0.765243 & $-3.009093^{* *}$ \\
IGDPgap & 0.811589 & $-3.330493^{\star *}$ & 0.096941 & $-3.416738^{* *}$ \\
IPW & -0.817447 & $-3.069961^{* *}$ & 0.290829 & $-3.183613^{* *}$ \\
IMS & -1.803649 & $-4.911129^{*}$ & 1.300255 & $-3.861958^{*}$
\end{tabular}

Critical values at $\mathbf{N}(\%)$

\begin{tabular}{lll}
1 & -3.699871 & -3.689194 \\
5 & -2.976263 & -2.971853 \\
10 & -2.627420 & -2.625121 \\
\hline
\end{tabular}

${ }^{*},{ }^{* *}$ and ${ }^{* * *}$ shows significance at 1,5 and $10 \%$ respectively.

the PP statistics are just modification of the ADF t-statistics that takes into account less restrictive nature of the error process. It is, therefore, the present study has also conducted PP test for the stationarity of the variables under consideration.

If all the variables under consideration were found to be stationary at level, then we may apply OLS method to estimate the relationship among the variables. However, if all the variables are not stationary at that level, but are integrated of order one or mix of integrated of zero and order one, we may still have a long run relationship if there exists a co-integration among these variables.

To examine the existence of cointegration among these variables, bound test procedure developed by Pesaran et al. (2001) has been used. In order to investigate the presence of long run equilibrium relationship among the variables, following unrestricted error correction model (UECM) as in Equation 2 can be estimated for bounds test procedure. The OLS method is used for estimation.

$$
\begin{aligned}
& \Delta l P_{t}=\alpha_{0}+\sum_{i=1}^{n} \alpha_{1 i} \Delta l P_{t-i}+\sum_{i=0}^{n} \alpha_{2 i} \Delta l N E E R_{t-i}+\sum_{i=0}^{n} \alpha_{3 i} \Delta l M S_{t-i} \\
& +\sum_{i=0}^{n} \alpha_{4 i} \Delta l P w_{t-i}+\sum_{i=0}^{n} \alpha_{5 i} \operatorname{GDPgap}_{t-i} \\
& +\beta_{1} l P_{t-1}+\beta_{2} l N E E R_{t-1}+\beta_{3} l M S_{t-1} \\
& +\beta_{4} l P w_{t-1}+\beta_{5} l \text { GUPgap }{ }_{t-1}+\varepsilon_{t}
\end{aligned}
$$

Where, $\Delta$ represents first difference and/is natural log of respective variables. Pesaran et al. (2001) proposed that the bound test is based on Wald coefficient test or F-statistics for cointegration analysis. The asymptotic distribution of the F-statistics is non standard under the null hypothesis of no cointegration relationship among the concerned variables, irrespective of whether the variables are I(0) or I(1). The test is conducted in following way. The null hypothesis considers the UECM in Equation 2 by excluding the lagged level variables $I P_{t-1}, I N E E R_{t-1}, I M S_{t-1}, I P w_{t-1}$ and IGDPgap $t_{t-1}$. More formally, a joint significance test is performed.

At conventional level of significance of 1,5 or $10 \%$, if the calculated $\mathrm{F}$-value falls outside the critical bound values tabulated at Pesaran et al. (2001), a conclusive inference can be made about accepting or rejecting the null hypothesis of no cointegration among the variables. If the F-value is greater than the upper limit of the bound values, we reject the null hypothesis that there is no cointegration between the variables under study. If the F-value is less than the lower limit of the bound value, then we accept the null hypothesis of no cointegration among these variables. However, if the calculated F-value falls within the critical bound limits, then the order of integration of the explanatory variables needs to be known before drawing any conclusion. From the estimated UECM, the long run elasticities is measured from the coefficients of the one lagged level explanatory variables divided by the coefficient of the one lagged level dependent variable and then multiplied by minus one. Short run elasticities are measured from the coefficient of the first differenced lagged variables in estimated UECM. To ascertain the goodness of fit of the autoregressive distributed lag (ARDL) model, relevant diagnostic tests are conducted. The diagnostic tests examine the normality, serial correlation, autoregressive conditional heteroscedasticity $(\mathrm{ARCH})$ associated with the model. RESET test is done to test for specification of the model.

\section{EMPIRICAL RESULTS AND ANALYSES}

On the priori, it is difficult to decide which method, ADF test or PP test, is better to use to examine the stationary nature of the variables.

Thus we conducted both the tests at level and at first difference with constant.

The result is shown in Table 1. The ADF result shows that all variables are non stationary at level but are stationary at first difference.

The Philips-Perron unit root test also confirms the ADF test result. Thus we may conclude that all the variables included in the model are integrated of order one that is I(1).

In order to examine the relationship between the inflation and these variables, the UECM version of ARDL model (Pesaran et al., 2001) with lag two is estimated. Then following Hendry's general to specific modeling approach, a parsimonious model is selected for equation by gradually deleting the insignificant coefficients. The result of the equation is presented in Table 2 . The diagnostic tests like Breusch-Godfrey serial correlation LM test, the ARCH test for heteroscedasticity, Jarque-Bera test for normality of the residual term, and Ramsey 
Table 2. Estimated ARDL model of inflation in Saudi Arabia.

\begin{tabular}{|c|c|c|}
\hline Variable & Coefficient & t-value \\
\hline $\mathbb{P}_{\mathrm{t}-1}$ & $-1.165477^{*}$ & -4.594796 \\
\hline $\mathrm{MS}_{\mathrm{t}-1}$ & $0.045582^{*}$ & 3.352755 \\
\hline NEER $_{\mathrm{t}-1}$ & $-0.400358^{*}$ & -5.333852 \\
\hline $\mathrm{PW}_{\mathrm{t}-1}$ & $0.364161^{*}$ & 5.006947 \\
\hline IGDPgap $_{\mathrm{t}-1}$ & $-0.410653^{* *}$ & -2.529715 \\
\hline $\mathrm{D} / \mathrm{MS}$ & $0.364873^{*}$ & 3.591738 \\
\hline $\mathrm{D} M \mathrm{MS}_{\mathrm{t}-1}$ & $0.455533^{*}$ & 3.576778 \\
\hline $\mathrm{DMS}_{\mathrm{t}-2}$ & $0.360474^{*}$ & 3.320081 \\
\hline D/NEER & $-0.114602^{\star *}$ & -2.501307 \\
\hline $\mathrm{D} / \mathrm{NEER}_{\mathrm{t}-1}$ & $0.226514^{*}$ & 3.119999 \\
\hline D/NEER $\mathrm{t}_{\mathrm{t}-2}$ & $0.244232^{*}$ & 3.742971 \\
\hline $\mathrm{D} / \mathrm{Pw}_{\mathrm{t}-2}$ & $-0.283975^{\star *}$ & -2.816858 \\
\hline D/GDPgap & $-0.378196^{\star \star *}$ & -2.082858 \\
\hline D/GDPgapt $-1_{1}$ & $-0.486158^{*}$ & -3.600425 \\
\hline D/GDPgapit-2 $_{\mathrm{t}}$ & $-0.424818^{*}$ & -3.522321 \\
\hline \multicolumn{3}{|l|}{ Diagonistic test } \\
\hline Adjusted R square & \multicolumn{2}{|l|}{0.67} \\
\hline Jarque-Bera normality test & \multicolumn{2}{|l|}{$0.151336[0.927]$} \\
\hline Breusch-Godfrey serial correlation LM test & \multicolumn{2}{|c|}{ (1): 0.158 [0.699], (2): 1.38 [0.299], (3): 1.423 [0.306] } \\
\hline $\mathrm{ARCH}$ test & \multicolumn{2}{|c|}{ (1): 1.957 [0.157], (2): 0.947 [0.404], (3): 0.684 [0.573] } \\
\hline Ramsey RESET & \multicolumn{2}{|c|}{ (1): $3.00 \mathrm{E}-05[0.996],(2): 0.688$ [0.527], (3): 0.792 [0.532] } \\
\hline
\end{tabular}

${ }^{*},{ }^{* *}$ and ${ }^{* * *}$ shows significance at 1,5 and $10 \%$ respectively. Values in square bracket are probability value.

Table 3. Bound test for cointegration analysis.

\begin{tabular}{ccc}
\hline \multicolumn{3}{c}{ Calculated F-value: 12.2150* } \\
\hline \multirow{2}{*}{ Significance level (\%) } & \multicolumn{2}{c}{ Critical bound } \\
\cline { 2 - 3 } & Lower bounds & Upper bounds \\
\hline 1 & 3.07 & 4.44 \\
10 & 2.26 & 3.48 \\
& 1.90 & 3.01 \\
\hline
\end{tabular}

The F-statistic (Wald test) is a joint test for the coefficients of $\mathbb{P}(-1), \mathbb{M S}(-1), \mathbb{N E E R}(-1), \mathbb{P} w(-1)$ and IGDP gap $(-1)$ all are set equal to zero. The reported bounds critical values are taken from Pesaran et al (2001), Table $\mathrm{Cl}(1)$ Case I: No intercept and no trend with four regressor case, p.300. ${ }^{*}$ Significant at $1 \%$.

RESET test for model specification also confirm the validity of the estimated equation.

The Breusch-Godfrey serial correlation LM test statistics rejected the first, second and third order serial correlation for the equation. The $\mathrm{ARCH}$ test for heteroscedasticity confirms that there is no problem of heteroscedasticity at first, second and third order. The Jarque-Bera statistic verifies that the estimated residual term has normal behavior, and the RESET test confirm the correct functional form of the equation.

The result of the bound test to examine the presence of long run relationship between inflation, money supply, exchange rate, world price level and GDP gap in Saudi
Arabia is given in Table 3. The result shows that the computed F-statistics based on the Wald test is greater than the critical upper bound value at $1 \%$ level. Thus we may conclude that there exists a long run relationship between these variables.

The degree of responsiveness of inflation in Saudi Arabia to exchange rate, world inflation, money supply and GDP gap is obtained by dividing the estimated coefficient of lag one level independent variables by estimated coefficient of lag level dependent variable and multiplied by negative sign. The long run and short run elasticities are shown in Table 4 . The negative coefficients for NEER and /GDP gap and positive coefficients 
Table 4. Long run and short run elasticity analysis.

\begin{tabular}{lcc}
\hline \multirow{2}{*}{ Variable } & \multicolumn{2}{c}{ Dependent variable inflation } \\
\cline { 2 - 3 } & Long run & Short run \\
\hline MS & $0.04^{*}$ & $1.18^{*}$ \\
NEER & $-0.34^{*}$ & $0.36^{*}$ \\
$\mathbb{P W}_{\mathrm{t}-2}$ & $0.31^{*}$ & $-0.28^{* *}$ \\
IGDPgap & $-0.31^{* *}$ & $-1.29^{*}$ \\
\hline
\end{tabular}

for money supply and world price are in consistent with our theoretical expectation. Depreciation of Riyal against non dollar currencies, world price and increase in money supply puts an upward pressure on inflation in the kingdom, and so long as actual output is less than the potential output, there will continue to be pressure on the price level in the country. As far as the magnitude of the coefficient is concerned, the result shows that in the long run, the world price level and supply bottleneck happen to be the dominating factor in influencing the inflation in Saudi Arabia. Thus in the long run, external factors have been found as major factors influencing the price level in the kingdom. The result of short run analysis shows that all the factors have significant relation with the inflation in the country. The direction of relationship is also in line with the long run relationship for all the variables except lagged world price which has negative sign. However, as against the long run relationship, in the short run, domestic factor like money supply and supply bottleneck dominate over the external factors.

\section{Conclusion}

The main objective of the paper has been to examine the determinants of inflation in Kingdom of Saudi Arabia in the short run and in the long run. For the purpose we applied bound test method developed by Pesaran et al. (2001). The result shows that domestic as well as external factors are responsible for inflation in the kingdom. In the long run, external factors appear to be more dominating than the domestic factors. Among the external factors, exchange rate and change in world price are important. The fixed exchange rate system followed by Saudi Arabia with US dollar causes depreciation of against non dollar currencies owing to depreciation of US dollar against major currencies. This makes the import costlier and put pressure on domestic price level. Inflation in world economy has further spillover effect on Saudi Arabia, thus reinforcing the pressure on price in the country. Among domestic factors, supply bottleneck has been an important factor influencing inflation in the country. Money supply, though has been a significant factor in the long run, its affect is relatively low. Its affect in the short run is high due to immediate increase in liquidity in the economy, in the long run the excess demand is matched by increase in import from the rest of the world. Supply bottleneck has been a significant factor in the short run also.

The afore-findings suggest that the inflationary pressure needs stabilization of domestic currency against major currencies. Since the country has fixed exchange rate system, this is less likely without doing away from the system. Increasing the domestic output may be the only alternative left to control inflation more so of production of commodities imported from rest of the world. This not only increases the supply of commodities and reduces the supply bottleneck, it also cushions against the effect of exchange rate depreciation and world inflation. Monetary policy may not be so effective as it has only marginal effect in the long run. Moreover, because of fixed exchange rate system, the country does not have autonomous monetary policy.

\section{REFERENCES}

Bonato L (2007). Money and inflation in the Islamic Republic of Iran. IMF working paper, 7: 119 (Washington: International Monetary Fund). Available on Internet (URL: www.imf.org/external/pubs/ft/wp/2007/wp07119.pdf).

Cheung C (2009). Are commodity prices useful leading indicator of inflation? Bank of Canada discussion Paper, p. 25.Available on Internet (URL: http//www.bankofcanada.ca/en/res/dp/2009/dp095.pdf).

Darrat A (1993). Inflation in Saudi Arabia: An econometric investigation. J. Econ. Stud., 12(4): 44-51.

De Brower G, Ericsson NR (1998). Modeling inflation in Australia. J. Econ. Bus. Stat., 4(16): 433-449.

Feldstein M (2008). Saudi Arabia should ditch its dollar peg. Available on Internet (URL: www.nber.org/feldstein/ft061808.html).

Hendry DF (1995). Dynamic econometrics. Oxford University Press, Oxford.

lyoha MA (1977). Inflation and openness in less developed economies: A cross-country analysis: Reply. Econ. Dev. Cult. Change, 26(1): 153-155.

Jin J (2000). Openness and growth: An interpretation of empirical evidence from East Asian countries. J. Int. Trade Econ. Dev., 9(1): 517.

Juselius K (1992). Domestic and foreign effects on prices in an open economy: The case of Denmark. J. Policy Model., 14(4): 401-428.

Kandil M, Morsy H (2009). Determinants of inflation in GCC. IMF, Working Paper, 9: 82. (Washington: International Monetary Fund). Available on Internet (URL: www.imf.org/external/pubs/ft/wp/2009/wp0982.pdf).

Keran M, Malik AA (1979). Monetary sources of inflation in Saudi Arabia. Federal Reserve Bank of San Francisco. Economic Review, winter issue supplement. Available on Internet (URL:http//www.frbsf.org/publications/economics/review/1979/econre v 79-1supp 1-27.pdf)

Khan MS, Schimmelpfenning A (2006). Inflation in Pakistan: Money or 
wheat. IMF Working Paper, 6: 60. (Washington: International Monetary Fund). Available on Internet (URL: www.imf.org/external/pubs/ft/wp/2006/wp0660.pdf).

Lim CH, Papi L (1997). An econometric analysis of determinants of inflation in Turkey. IMF Working Paper, 97: 170. (Washington: International Monetary Fund). Available on Internet (URL: www.imf.org/external/pubs/ft/wp/wp97170.pdf).

Metin K (1995). An integrated analysis of Turkish inflation. Oxf. Bull. Econ. Stat., 57(4): 412-422.

Onis Z, Ozmucur S (1990). Exchange rates, inflation and money supply in Turkey: Testing the vicious circle hypothesis. J. Dev. Econ., 32(1): 133-154.
Pesaran MH, Shin Y, Smith RJ (2001). Bound testing approaches to the analysis of level relationships. J. Appl. Econom., 16: 289-326.

Philips PCB, Perron P (1988). Testing for a Unit Root in time series regression. Biometrica, 75(2): 335-346.

Sekine T (2001). Modeling and forecasting inflation in Japan. IMF Working Paper 01/82, (Washington: International Monetary Fund). Available on Internet www.imf.org/external/pubs/ft/wp/2001/wp0182.pdf).

(URL: 